Є.Ю. Іленко ${ }^{1}$, М.Б.Сушак ${ }^{2}$, П.М. Стешенко ${ }^{2}$

${ }^{1}$ Харківський начіональний університет Повітряних Сил ім. І. Кожедуба, Харків

2 Держсвний науково-дослідний інститут авіації, Київ

\title{
ВИРІШЕННЯ ЗАДАЧІ МІНІМІЗАЦІЇ РИЗИКІВ ІМПОРТОЗАМІЩЕННЯ В ПРОЦЕСІ ЗАВОДСЬКОГО РЕМОНТУ ВІЙСЬКОВОЇ АВІАЦІЙНОЇ ТЕХНІКИ В УМОВАХ ОСОБЛИВОГО ПЕРІОДУ
}

У статті представлені результати аналізу питання забезпечення післяремонтної надійності військової авіаційної техніки при налагодженні виготовлення комплектуючих деталей (запасних частин, агрегатів) вітчизняними підприсмствами у процесі імпортозаміщення та наведені рекомендації щзодо мінімізаціі ризиків імпортозаміщення прочесів заводського ремонту в умовах особливого періоду. Рекомендації стосуються державної політики у сфері оборони, законодавчої бази на технічну документачію підприємств, заходів щуодо матеріалознавства та технології виробництв, врахування залежності рівня надійності від конструктивно-схемних рішень.

Ключові слова: авіаційне ремонтне підприсмство, імпортозаміщення, ризик, заводський ремонт, надійність, ресурс, рівень справності, особливий період.

\section{Вступ}

Постановка проблеми. На сьогоднішній день основними напрямками забезпечення справності військової авіаційної техніки є: виконання капітального ремонту із встановленням міжремонтних показників з відповідним продовженням призначеного строку служби; переведення на експлуатацію авіаційної техніки (далі - АТ) за технічним станом шляхом виконання контрольно-відновних робіт з виготовленням комплектуючих (запасних частин, агрегатів) у процесі імпортозаміщення. Тому особливе значення для прогнозованого планування заходів інженерно-технічного забезпечення є аналіз ризикоутворюючих чинників саме за цими напрямами.

Для забезпечення достатнього рівня післяремонтної надійності АТ при виконанні заходів заводського ремонту мають бути досліджені всі можливі ризикоутворюючі чинники та відповідно оцінені ризики реалізації цих заходів.

Аналіз діяльності авіаремонтних підприємств (далі - АРП) України свідчить про існування низки проблемних питань, які негативно впливають на поточний стан авіаремонтної бази та перспективи розвитку, що потребує невідкладного вжиття відповідних заходів. При цьому, характерними особливостями сьогоднішнього стану більшості АРП є:

- фактичне вичерпання попередніх напрацювань, технологічних можливостей i виробничого потенціалу більшості підприємств для "відносно швидкого і дешевого” освоєння заводського ремонту та виготовлення при цьому запасних частин й комплектувальних виробів;

- потреба в значних капіталовкладеннях для реалізації імпортозаміщення в процесах заводського ремонту зразків військової авіаційної техніки;

- значні часові терміни освоєння нових виробництв та ремонтних робіт;

- практична відсутність у підприємств досвіду, необхідного обладнання, персоналу, документації для виготовлення нової номенклатури запасних частин до авіаційної техніки;

- дрібносерійне й тому нерентабельне виробництво;

- відсутність конкуренції, об'єктивне звуження кола підприємств, що мають необхідні ресурси для освоєння нових виробництв та ремонтних робіт [1].

Зазначені особливості визначають доцільність формування управлінських рішень щодо заводського ремонту та технічної експлуатації авіаційної техніки державної авіації з позицій мінімізації потенційних ризиків. При цьому необхідно враховувати наступні умови:

- нагальна потреба у відновленні та створенні перспективних виробничих потужностей для забезпечення заданого рівня справності парку АТ з урахуванням розвитку можливих сценаріїв особливого періоду;

- невідкладність створення нових коопераційних зв'язків і каналів постачання матеріалів, вузлів і комплектуючих як всередині країни, так і ззовні (диверсифікація), для забезпечення ремонту та відновлення АТ, яка перебуває на озброєнні 3С України, вирішення проблеми імпортозаміщення;

- необхідність організації раніше нетрадиційного для України виду військово-технічного співробітництва 3 іноземними державами - імпорту вузлів і комплектуючих (запасних частин) в умовах відсутності сталих каналів постачання та політичних обмежень з боку низки країн СС та НАТО щодо про- 
дажу Україні товарів подвійного використання;

- невідповідність нормативно-правової бази, що врегульовує порядок ввезення та легалізації вузлів і комплектуючих (запасних частин), отриманих за імпортом та створеного в умовах особливого періоду, невідкладним потребам оборони держави, а відтак - необхідність внесення відповідних змін до законодавства.

Постановкою задачі $є$ розробка та обгрунтування рекомендацій щодо мінімізації ризиків імпортозаміщення процесів заводського ремонту військової авіаційної техніки в умовах особливого періоду.

Метою статті є висвітлення результатів досліджень щодо питання забезпечення післяремонтної надійності військової авіаційної техніки при налагодженні виготовлення комплектуючих деталей (запасних частин, агрегатів) вітчизняними підприємствами в процесі імпортозаміщення, відпрацювання рекомендацій щодо мінімізації відповідних ризиків.

\section{Виклад основного матеріалу}

Діяльність вітчизняних АРП впродовж останніх п'яти років перебуває під негативним впливом кардинальних змін, що відбулися в Україні та поза їі межами, а саме:

- військова агресія Російської Федерації проти України, що обумовило різке зростання потреб Збройних Сил України у справних та боєготових зразках авіаційної техніки;

- втрата Україною контролю над низкою підприємств, розташованих на тимчасово окупованій РФ території АР Крим і міста Севастополь (Державне підприємство "Севастопольське авіаційне підприємство”, ДП “Свпаторійський АРЗ”), окремих районів Донецької і Луганської областей (ДП “Луганський авіаційний ремонтний завод”);

- припинення традиційних коопераційних зв'язків із підприємствами РФ (частка вузлів і комплектуючих (запасних частин) якої у кінцевій продукції складала від 40 до 70\%) в умовах відсутності в Україні замкнених виробничих циклів щодо більшості номенклатури ОВТ;

- політичні обмеження з боку низки країн $\mathrm{CC}$ та НАТО щодо експорту в Україну товарів військового призначення та подвійного використання.

При цьому також необхідно враховувати специфічні особливості функціонування державного концерну "Укроборонпром" як системи господарювання на такому конкурентному та політизованому ринку, як ринок озброєння та спеціальних послуг.

Насамперед, це стосується назрівшої потреби у реструктуризації та фінансовому оздоровленні підприємств-учасників, їх корпоратизації, створенні на корпоративній основі інтегрованих наукововиробничих структур, технічного переоснащення i технологічного оновлення науково-виробничої та експериментально-випробувальної бази підприємств 3 використанням новітніх досягнень науковотехнічного прогресу.

Проблемним питанням діяльності підприємств вітчизняного ОПК, яке не дозволяе на сьогодні забезпечити існуючі потреби нашої країни в озброєнні, військовій і спеціальній техніці, особливо серійного виробництва нових і модернізованих зразків АТ, є не стільки стан виробничих фондів і показник фондовіддачі, а насамперед малий i неритмічний обсяг замовлень, що є головним чинником стримування залучення інвестицій у розвиток наукововиробничої бази.

Ситуація погіршується ще й тим, що окремі договори (контракти) про надання послуг з ремонту (ремонту та модернізації) зразків АТ укладаються 3 приватними підприємствами без достатньої кваліфікації та досвіду, а державні підприємства залишаються без замовлень.

Так, до виконання оборонних замовлень все частіше залучаються невеликі приватні компанії, які не завжди здатні забезпечити в задані терміни належну якість робіт і подальше гарантоване технічне супроводження відремонтованої (модернізованої) техніки у міжремонтний період, на відміну від профільних державних підприємств.

Система забезпечення справності авіаційної техніки державної авіації $є$ складною багатофакторною істотно нелінійною та нестаціонарною системою, тому одним із доцільних підходів до оцінки впливу ризикоутворюючих чинників на забезпечення заданого рівня справності парку авіаційної техніки є розгляд аналогій для системи адекватної складності [2-3].

В якості такої системи можна розглядати систему АРП при виконанні заходів імпортозаміщення 3 відповідними ризиками. На теперішній час найбільш вагомими ризиками реалізації заходів імпортозаміщення в процесі заводського ремонту АТ державної авіації, за якою не здійснюється авторський нагляд є:

- неосвоєння в рамках імпортозаміщення нових (зазвичай високотехнологічних) виробництв та ремонтних робіт (наприклад виробництво (ремонт) лопатей несучого та рульового гвинта до військових вертольотів);

- незабезпечення необхідної якості виготовлення директивних запасних частин й комплектувальних виробів (ремонту) (наприклад виготовлення підшипників до авіаційних двигунів, редукторів, робочих лопаток турбін та плунжерних пар паливних насосів до авіаційних двигунів, силових елементів основних стійок шасі, інше);

- критична залежність від одного виробника (часто приватного);

- неефективне використання державних коштів 
на реалізацію заходів імпортозаміщення.

Зазначені ризики є прямими аналогами ризиків забезпечення справності авіаційної техніки державної авіації при капітально-відновлювальному ремонті, тому, масштаб та наслідки їх впливу розглядається як “орієнтир" для оцінки можливого масштабу впливу та наслідків щодо системи заводського ремонту АТ в цілому.

Ризик зриву освоєння в рамках імпортозаміщення нових виробництв та ремонтних робіт полягає у наявності ймовірності недосягнення встановлених цілей запланованих заходів імпортозаміщення. Джерелом виникнення даного ризику є невідповідність інтересів замовника освоєння та підприємства-виконавця і обмежена можливість економічного стимулювання виконавця з боку замовника, яка обмежена виключно умовами укладеного договору (контракту) [1]. Наявність значної ймовірності зриву освоєння нових виробництв та ремонтних робіт 3 причин, що не пов'язані з діяльністю замовника, а також вкрай негативні наслідки цього дозволяють віднести даний ризик до вагомих ризиків.

Ризик незабезпечення необхідної якості виробництва (ремонту) визначається відсутністю у підприємств досвіду, необхідного технологічного обладнання, достатньо підготовленого персоналу, якісної сировини, повного комплекту конструкторськотехнологічної документації для виготовлення нової номенклатури запасних частин до АТ. Залучення до процесу імпортозаміщення в сфері державної авіації приватних підприємств, які не мають відповідної системи управління якістю, досвіду співпраці 3 військовими представництвами замовника тільки збільшує вплив даного виду ризику. Ризик незабезпечення необхідної якості виробництва (ремонту) $є$ значним. Негативні наслідки неякісного виробництва (ремонту) дозволяють віднести зазначений ризик до вагомих ризиків.

Ризик критичної залежності від одного приватного виробника $є$ специфічним для чинної економічної системи забезпечення матеріально-технічних потреб державної авіації. Потреба в значних капіталовкладеннях для реалізації подальших планів імпортозаміщення та значні часові терміни освоєння нових виробництв та ремонтних робіт визначають необхідність витрати великого обсягу обігових коштів підприємств для освоєння ремонту та дрібносерійного виготовлення запасних частин й комплектувальних виробів, які необхідні при ремонті. Це $є$ об'єктивним чинником звуження кола підприємств, що мають достатні ресурси для освоєння нових виробництв (ремонтних робіт) та забезпечує відсутність конкуренції на ринку імпортозаміщення в сфері державної авіації України.

Для замовника монопольне положення підприємств, особливо приватних, призводить до критич- ної залежності від них та невиправданого завищення цін на їх продукцію (послуги). Обмежені можливості замовника щодо економічного стимулювання виробників визначають доцільність віднесення зазначеного ризику до вагомих.

Ризик неефективного використання державних коштів на реалізацію заходів імпортозаміщення визначається відсутністю повної та достовірної інформації про реальні можливості підприємств, про стан зовнішнього середовища, про потенційні небезпеки, як виробничого, так і технологічного характеру.

Необхідність прийняття управлінських рішень в умовах неповної інформації, невизначеності, нестаціонарності оцінок не гарантує раціонального використання державних ресурсів на реалізацію заходів імпортозаміщення.

Обмежені фінансові можливості України на реалізацію заходів імпортозаміщення в сфері державної авіації визначають доцільність віднесення зазначеного ризику до вагомих.

На рис. 1 наведена схема управління ризиком.

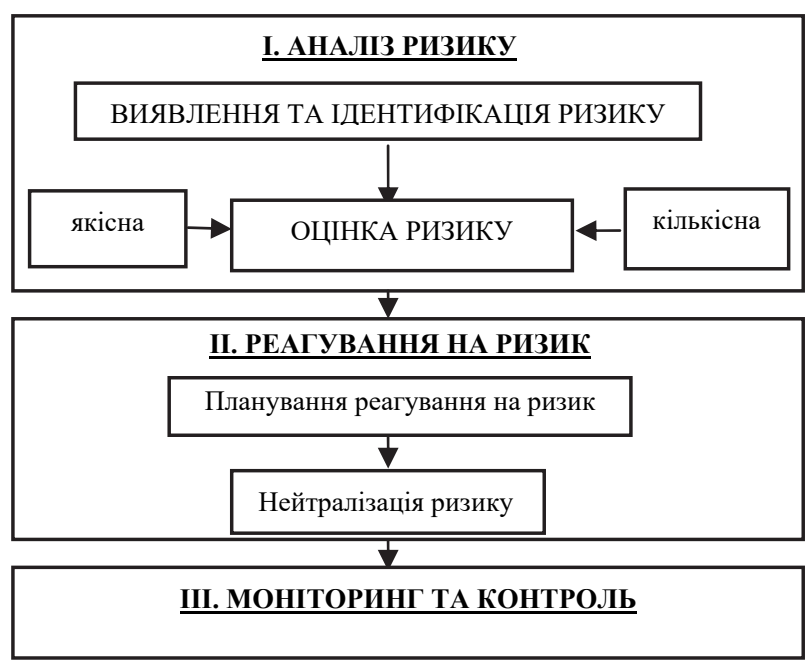

Рис. 1. Схема управління ризиком Джерело: [4, С. 77].

Для кількісного оцінювання ризику існують різні методи, серед яких найпоширенішими є: статистичний (у тому числі метод статистичних випробувань і метод Монте-Карло); аналітичний; поєднання дерева рішень та імовірнісного підходу; оцінювання фінансової стійкості або оцінювання доцільності витрат; експертних оцінок; нормативний; аналізу чутливості; використання аналогів тощо. Кожний 3 цих методів має переваги та недоліки і використовується у конкретних ситуаціях, а універсального методу, прийнятого для всіх випадків, в тому числі, i при оцінці ризиків реалізації заходів імпортозаміщення процесів заводського ремонту та технічної експлуатації АТ, не існує [4-5]. Базовою вимогою до методу мінімізації ризиків є відповідність загальному системному підходу до планування як методо- 
логічному фундаменту для пошуку оптимальних управлінських рішень. Вимоги системності планування полягають в такому:

- процес прийняття рішень повинен починатися з виявлення і формування кінцевих цілей;

- проблему необхідно розглядати як єдину систему і виявляти всі наслідки і взаємозв'язки кожного окремого рішення;

- обов'язковий аналіз можливих альтернативних шляхів досягнення цілей;

- цілі підпрограм або етапи рішення не повинні суперечити цілям всієї програми.

Алгоритм формування плану ремонту АТ шляхом ітераційного процесу, при якому досягається мінімальний ризик забезпечення заданого рівня справності парку АТ державної авіації наведено на рис. 2. Для кожного зі сценаріїв особливого періоду розглядається окремий варіант плану ремонту АТ.

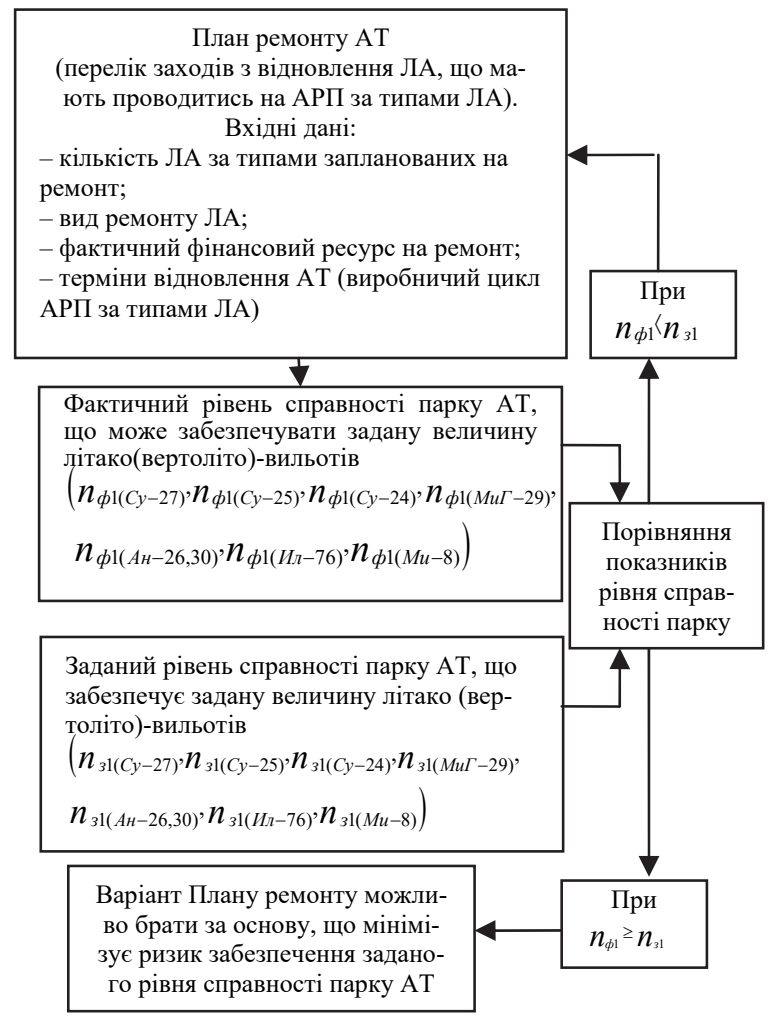

де $n_{\phi 1}$ - фактична кількість справних ЛА за типами;

$n_{31}$ - задана кількість справних ЛА за типами.

Рис. 2. Алгоритм формування плану ремонту АТ, при якому досягається мінімальний ризик забезпечення заданого рівня справності парку державної авіації для кожного $з$ можливих сценаріїв особливого періоду

Джерело: розроблено авторами.

Закони розподілу відмов є випадковими величинами, та мають велике значення для теорії і практики робіт щодо забезпечення надійності виробів
АТ. Знання цих законів дозволяє розраховувати та прогнозувати надійність виробів на етапах їх проектування та випробувань, особливо велике значення ці закони мають при оцінці правильності встановлення та продовження ресурсу зразків АТ [6-10]. 3 великої кількості різноманіття законів розподілу випадкових величин, існуючих в теорії ймовірностей, найбільше значення для надійності мають біноміальний та Пуассона - для дискретних величин; експоненціальний, Вейбулла та нормальний - для неперервних величин.

Аналіз можливості застосування методичних підходів, викладених у [16], показав, що вони можуть бути певною мірою застосовані для оцінювання таких програмних заходів (далі - ПЗ), як заводський ремонт та серійна модернізації літальних апаратів (далі - ЛА), але ПЗ з імпортозаміщення процесів заводського ремонту військової авіаційної техніки в умовах особливого періоду залишаються поза їх межами.

На думку авторів слушним є підхід, викладений в [14], де пропонується розглядати реалізовність $j$-го ПЗ $\left(\Omega_{j}\right)$ як очікуваність успішної його реалізації - величину зворотну ймовірності виникнення визначального ризику реалізації $j$-го ПЗ $\left(p_{j}\right)$ :

$$
\Omega_{j}=\left(1-p_{j}\right) \cdot 100 \% .
$$

При цьому під “визначальними” в роботі [14] розуміються ризики, настання яких є критичним для успішної реалізації ПЗ та може призвести до невиконання (зриву) ПЗ в цілому.

На думку авторів таке трактування визначального ризику ПЗ є досить розмитим та складним для розуміння по відношенню до закупівельного проекту (далі - ЗП).

Пропонується під визначальним ризиком ЗП розуміти випадкову подію комплексного впливу основних ризикоутворюючих факторів, що супроводжують ЗП. Кількісною оцінкою такого результату є ймовірність настання визначального ризику ЗП, обумовленого впливом ризикоутворюючих факторів.

Зважаючи на об'єктивні труднощі визначення величини ймовірності ризику класичними методами теорії ймовірності та статистичного аналізу, для кількісного оцінювання показника реалізовності ПЗ у [14] пропонується розрахунок імовірності виникнення визначальних ризиків ПЗ здійснювати на основі синтезу науково-методологічних апаратів теорії ризиків і теорії нечітких множин.

Математичний апарат теорії нечітких множин дозволяє оцінювати параметр імовірності (або в термінах теорії нечітких множин - “очікуваності”) певної події в умовах невизначеності при відсутності достатнього обсягу статистичної інформації та 
неможливості формалізації (моделювання) стохастичних процесів, що досліджуються [14-18].

Авторами пропонується удосконалення методичного підходу до оцінювання очікуваності настання визначального ризику ПЗ, викладеного в [14], в частині його адаптації до особливостей такого програмного заходу, як ЗП, уточнення та за потреби розширення переліку основних ризикоутворюючих факторів, що впливають на успішність реалізації ЗП, і застосування алгоритму нечіткого логічного виводу Сугено.

Для зменшення ризику критичної залежності від одного приватного виробника необхідних для ремонту та експлуатації АТ комплектувальних виробів, аналогічних штатним, доцільнім є розвиток державної системи економічного стимулювання (надання преференцій, державної підтримки) вітчизняних підприємств, що задіяні в процесі імпортозаміщення.

Для цього доцільним $є$ ініціювання питання практичної реалізації державної підтримки вітчизняних підприємств, які задіяні в процесі імпортозаміщення в галузі державної авіації з виділенням на це відповідного фінансового ресурсу з Державного бюджету України.

Доцільними заходами мінімізації ризику для забезпечення післяремонтної надійності військової авіаційної техніки при налагодженні виготовлення комплектуючих деталей (запасних частин, агрегатів) вітчизняними підприємствами в процесі імпортозаміщення, в якості рекомендацій пропонується:

- створення загального національного реєстру імпортозаміщення за номенклатурним каталогом продукції оборонного призначення, яка потребує імпортозаміщення або диверсифікації закупівель. Розроблення орієнтованих під життєвий цикл авіаційної техніки державної авіації баз даних (каталогів) імпортозаміщення по авіаційним матеріалам, елементній базі, агрегатам та комплектувальним виробам із періодичною їх актуалізацією дозволить виключити зайве дублювання освоєння та зменшити ціни на необхідні для ремонту і експлуатації АТ комплектувальні вироби, аналогічні штатним;
- поширення дії Закону України "Про страховий фонд документації” на технічну документацію, що створюється підприємствами України у процесі виконання заходів імпортозаміщення в галузі державної авіації України;

- в ході ремонту обов'язково мають бути враховані закономірності залежності рівня надійності АТ від результатів розрахункового аналізу, що реалізуються в ході імпортозаміщення, конструктивносхемних рішень та випробувально-досліджувальних робіт для вибору та обгрунтування раціонального способу забезпечення необхідного рівня надійності та виконання технічних вимог, які визначені для кожного типу літального апарату розробником [1112];

- освоєння необхідного об'єму знань в області матеріалознавства та технології, включаючи раціональний вибір матеріалів та технологічних процесів для забезпечення надійності, експлуатаційних характеристик (ресурсних показників) деталей, агрегатів і систем, виготовлення яких налагоджується вітчизняними підприємствами в ході імпортозаміщення в строгій відповідності встановленим технічним умовам (стандарту) [11-12].

\section{Висновки}

Таким чином, для мінімізації ризиків імпортозаміщення процесів заводського ремонту військової авіаційної техніки в умовах особливого періоду необхідно експлуатуючим частинам проводити постійний моніторинг процесів забезпечення достатнього рівня післяремонтної надійності АТ для своєчасного виявлення слабких місць та для оперативної підготовки спільно з підприємствами відповідних заходів щодо ефективного усунення недоліків та їх запобігання. При цьому, особливу увагу слід приділяти дотриманню вимог щодо взаємовідношень схваленої (сертифікованої) організації та не схваленої організації при виконанні будь-якого процесу, який впливає на відповідність комплектувальних виробів (деталей), виготовлених в процесі імпортозаміщення, пред’явленим вимогам.

\section{Список літератури}

1. Сушак М.Б. Оцінка ефективності та проблемні фінансові, економічні та виробничо-технологічні питання впровадження на підприємствах України імпортозаміщення під час заводського ремонту авіаційної техніки / М.Б. Сушак, В.К. Борохвостов, О.М. Рябець // Збірник наукових праць Центрального науково-дослідного інституту озброєння та військової техніки Збройних Сил України. - 2019. - № 2(73). - С. 71-79.

2. Анцелович Л.Л. Надежность, безопасность и живучесть самолёта / Л.Л. Анцелович. - М.: Машиностроение, 1985. $-296 \mathrm{c}$.

3. Barlov R.E. Mathematical models for system reliability / R.E. Barlov, L.C. Hunter // The Sylvania Technologist. - 1960. - № 1(2). - P. 121-125.

4. Шапкин А.С. Теория риска и моделирование рискованных ситуацій / А.С. Шапкин, В.А. Шапкин. - М.: Машиностроение, 2005. - 880 с.

5. Райнзберг Б.А. Предпринимательство и риск / Б.А. Райнзберг. - М.: Знание, 1992. - 240 с.

6. Іленко С.Ю. Визначення міжремонтного ресурсу авіаційних двигунів у процесі імпортозаміщення комплектуючих виробів / С.Ю. Іленко, М.Б. Сушак, П.М. Стешенко // Системи озброєння і військова техніка. - 2018. - № 4(56). C. 19-26. https://doi.org/10.30748/soivt.2018.56.03. 
7. Справочник по надёжности / Пер. с англ.; Под ред. Б.Е. Бердичевского. - М.: Мир, 1969, 329 с.

8. Эксплуатационная надёжность и режим технического обслуживания самолётов / Н.Н. Смирнов, А.М. Андронов, Н.И. Владимиров, Ю.И. Лемин. - М.: Транспорт, 1974. - 303 с.

9. Смирнов Н.И. О применении технической диагностики для определения сроков замены самолётных агрегатов / Н.И. Смирнов, А.А. Ицкович, В.И. Загребельный. - М.: Наука, 1972. - 69 с.

10. Смирнов Н.И. Иерархическая структура показателей эффективности процесса эксплуатации летательных аппаратов / Н.И. Смирнов, А.А. Ицкович, Ю.М. Чинючин // Техническое обслуживание и ремонт авиационной техники. 1978. - № 2. - С. 1-7.

11. Акимов В.М. Основы надежности газотурбинных двигателей / В.М. Акимов. - М.: Машиностроение, 1981. - 207 с.

12. Новожилов Г.В. Надёжность широкофюзеляжных самолётов / Г.В. Новожилов // Вестник Академии наук. 1985. - № 8. - С. 93-101.

13. Луханин М.И. Основы научно-методического обеспечения оценки реализуемости государственных программ и проектов: монография / М.И. Луханин. - К.: КИТ, 2002. - 206 с.

14. Мавренков О.С. Оцінювання реалізованості програмних заходів з технічного оснащення авіації Збройних Сил України / О.С. Мавренков // Збірник наукових праць Національного Університету Оборони України. - 2016. - № 1(134). - C. 198-204.

15. Кофман А. Введение в теорию нечетких множеств / А. Кофман. - М.: Радио и связь, 1982. - 135 с.

16. Мациевский С.В. Нечеткие множества / С.В. Мациевский. - Калининград: Изд-во КГУ, 2004. - 234 с.

17. Рыбин В.В. Основы теории нечетких множеств и нечеткой логики / В.В. Рыбин - М.: Изд-во МАИ, 2007. - 96 с.

18. Хаптахаева Н.Б. Введение в теорию нечетких множеств / Н.Б. Хаптахаева, С.В. Дамбаева, Н.Н. Аюшева. Улан-Удэ: Изд-во ВСГТУ, 2004. - 68 с.

\section{Відомості про авторів:}

\section{Іленко Євген Юрійович}

кандидат технічних наук доцент

заступник начальника кафедри

Харківського національного університету

Повітряних Сил ім. І. Кожедуба,

Харків, Україна

https://orcid.org/0000-0001-9405-6598

\section{Сушак Михайло Борисович}

кандидат технічних наук

старший науковий співробітник

начальник науково-дослідної лабораторії

Державного науково-дослідного інституту авіації,

Київ, Україна

https://orcid.org/0000-0001-7747-2303

\section{Стешенко Петро Миколайович}

кандидат технічних наук

науковий співробітник

Державного науково-дослідного інституту авіації,

Київ, Україна

https://orcid.org/0000-0003-1432-6864

\section{Information about the authors:}

\author{
Yevhen Ilenko \\ Candidate of Technical Sciences Associate Professor \\ Deputy Chief of Department \\ of Ivan Kozhedub Kharkiv National \\ Air Force University, \\ Kharkiv, Ukraine \\ https://orcid.org//0000-0001-9405-6598
}

\author{
Mikhail Sushak \\ Candidate of Technical Sciences \\ Senior Research \\ Chief of Research Laboratory \\ of State Research Aviation Institute \\ Kyiv, Ukraine \\ https://orcid.org/0000-0001-7747-2303
}

\section{Petr Steshenko}

Candidate of Technical Sciences

Research Associate

of State Research Aviation Institute

Kyiv, Ukraine

https://orcid.org/0000-0003-1432-6864

\title{
РЕШЕНИЕ ЗАДАЧ МИНИМИЗАЦИИ РИСКОВ ИМПОРТОЗАМЕЩЕНИЯ ПРОЦЕССОВ ЗАВОДСКОГО РЕМОНТА ВОЕННОЙ АВИАЦИОННОЙ ТЕХНИКИ В УСЛОВИЯХ ОСОБОГО ПЕРИОДА
}

\author{
Е.Ю. Иленко, М.Б. Сушак, П.Н. Стешенко
}

В статье представлены результаты анализа вопроса обеспечения послеремонтной надёжности военной авиачионной техники при налаживании изготовления комплектующих деталей (запасных частей, агрегатов) отечественными предприятиями в процессе импортозамещения и предложены к рассмотрению соответствующие рекомендации. Рекомендачии касаются государственной политики в сфере обороны, законодательной базы на техническую документацию предприятий, мероприятий в области материаловедения и технологии производства, учета зависимости уровня надежности от конструктивно-схемных решений.

Ключевые слова: авиачионное ремонтное предприятие, импортозамещение, риск, заводской ремонт, надежность, ресурс, исправность, особый период. 


\section{SOLUTION FOR TASK MINIMIZATION RISKS OF IMPORT SUBSTITUTION IN THE PROCESS OF MILITARY AEROTECHICS FACTORY REPAIR IN THE CONDITIONS OF THE SPECIAL PERIOD}

Ye. Ilenko, M. Sushak, P. Steshenko

The article presents the analysis results of the question of ensuring the post-repair reliability of military aviation equipment, while adjusting the production of component parts (spare parts, units) by domestic enterprises in the process of import substitution. System of aviation equipment maintenance of state aviation is a complex multifactorial, essentially nonlinear and non-stationary system, so one of the expedient approaches to assessing the influence of risk-forming factors on ensuring a given level of serviceability of a fleet of aviation equipment is to consider analogies for a system of adequate complexity. Such system is considered the system of aircraft repair company when performing import substitution measures with appropriate risks. The most significant risks of the implementation of measures of import substitution in the process of factory repair of aviation equipment of state aviation, which are not subject to copyright supervision, are listed. Each risk is characterized. The algorithm of formation of the plan of repair of aviation equipment, at which the minimal risk of providing the set level of serviceability of the state aviation park for each of the possible scenarios of a special period is presented. Quantitative evaluation of the measure of the feasibility of a program measure is carried out by calculating the probability of occurrence of determining risks on the basis of the synthesis of scientific and methodological apparatus of risk theory and fuzzy sets theory. The authors propose to improve the existing methodological approach to assessing the expectation of the occurrence of a specific risk of a program measure in terms of its adaptation to the features of a program measure such as the procurement project, clarification and extension of the list of major risk-forming factors affecting the success of the procurement and implementation project Sugeno. Recommendations are given to minimize the risks of import substitution of factory repair processes in the special period. The recommendations relate to the state defense policy, the legal basis for the technical documentation of enterprises, measures on materials science and production technology, taking into account the dependence of the level of reliability on the design and schematic solutions.

Keywords: aviation repair enterprise, import substitution, risk, factory repair, post-repair reliability, resource, level of good condition, special period. 